\title{
USE OF THE ImageJ PROGRAM TO ASSESS THE DAMAGE OF PLANTS BY SNAILS
}

\author{
ZASTOSOWANIE PROGRAMU ImageJ \\ DO OCENY USZKODZEŃ ROŚLIN PRZEZ ŚLIMAKI
}

\begin{abstract}
Laboratory tests using image analysis are one of the types of experimental methods in plant protection. They are used in the evaluation of crop damage by pests, also useful in testing the effectiveness of active substances of plant protection products. The most popular of these analyses are the so called "circular tests", comprising in administering to the insects and snails the fragments of leaves and measuring the amount of consumed surface. The paper presents a method of analysis of damage to lettuce leaves using ImageJ application. The way of presenting the results was also proposed. This procedure can be used in various analyses of biological sciences and evaluating the dietary preferences of pests. Access to the application ImageJ is free, and flexible configuration allows for any setting parameters of the program, the opportunity to work in different environments and low system requirements allow you to make many accurate measurements in a short time without the need to purchase expensive specialized hardware.
\end{abstract}

Keywords: ImageJ, snail, slug, damage to plants, graphical analysis, image analysis, assessment of impairment

\section{Introduction}

Development of image analysis techniques has been going on since the middle of the twentieth century, and they are used in many areas of life. The combination of the computer systems with image processing technologies and modern technologies of high-speed digital circuits, high-performance processors, efficient programming methods, as well as "artificial intelligence" and networks often provides also the foundation for modern science $[1,2]$. Intensive development of modern information technology and greater public awareness is associated with general access to the hardware together with an increase of computing power, which makes it possible to apply an increasing range of research methods [3]. Image analysis, namely the use of electronic devices to interpret formulas stored in digital form [1], the result of which are the data expressed in numeric or symbolic form [2], may, because of repeatability, reproducibility and objectification, undoubtedly accelerate the

\footnotetext{
${ }^{1}$ Department of Ecotoxicology, Institute of Applied Biotechnology and Basic Science, University of Rzeszow, Werynia 502, 36-100 Kolbuszowa, Poland

${ }^{2}$ Department of Botany, Institute of Applied Biotechnology and Basic Science, University of Rzeszow, Werynia 502, 36-100 Kolbuszowa, Poland

*Corresponding author: kstawarczyk2@o2.pl
} 
laborious measurements, increase research capacity and solve many of the problems associated with them, as well as lead to broadening the horizons of contemporary knowledge [1, 3, 4].

The methods of image analysis are widely used, among others, in medical institutions, diagnostic laboratories and academic institutions [2]. They are also widely used in various sectors of the economy, most commonly in the industry $[2,5,6]$. In agriculture, computer image analysis methods were applied during the study related to the protection of plants [7], for example, they are used to identify pests and diseases [3, 4], as well as to assess the quality of agricultural products and process efficiency [1, 8-10]. These applications are also part of various processes [11].

The present work aims to illustrate the method of application of ImageJ to assess the amount of damage to plants by snails after applying pesticides on lettuce.

\section{Materials and methods}

\section{ImageJ - description}

Image J is a tool which constitutes an adaptation of the NIH Image program, designed for Macintosh computers with operating system Mac OS, for systems supporting Java. This created the possibility of use of the software among others on Windows and Linux systems. Like its prototype, Image J is made available on the basis of a public domain software, providing free use of the tool for non-commercial purposes. The author of this program is Wayne Rasband (National Institutes of Health) [12].

The program allows to perform most of the standard measurements and analyses of digital video (viewing, editing, processing, storing, and printing). In addition, because of the used environment (Java) it is possible to change or expand ImageJ capabilities through the installation of so-called Plug-ins [13], that can be created personally, as well as downloaded from the website of the program. The program works with 8,16 and 32 bit images, both in shades of grey (greyscale) and colour. This tool supports a number of basic types of reading and saving graphics, among which we can find files in such formats like TIFF, GIF, JPEG, PNG, DICOM, BMP, PGM, FITS, and videos.

This tool is widely used, among others, in scientific research related to medical diagnostics [13-16], experimental biology [17-19], environmental analysis [5, 6] technology [20]. You can also find in the literature the use of the program in the evolutionary analysis of morphological changes [21] and astrophysics [22].

\section{Experimental study}

The program ImageJ $1.45 \mathrm{i}$ was used to assess the effects of chemical pesticides on the feeding activity of juvenile and adult forms of A. lusitanicus Mabille 1868. Study was performed in 2010-2012 at the Institute of Applied Biotechnology and Basic Sciences of University of Rzeszow. The used snails were collected from a private farm situated in the area of Sanok (Subcarpathian Voivodeship). As food and at the same time the basis for pesticides served fresh leaves of lettuce (Lactuca sativa L.), Krolowa Majowych (May Queen) variety from own cultivation.

Before analysis, the animals were fasted for $48 \mathrm{~h}$, and were acclimatized to the environmental conditions. After this period, each animal was weighed and then placed in a container with slices of lettuce leaves of known weight and surface area. Before administration to snails, leaves were immersed for 180 seconds in a solution of pesticides 
(in the control sample in distilled water). Snails with food were placed individually for a given period of time.

\section{Measurements of leaf area}

Measurements of leaf area were made by means of a composition which consisted of scanning device - Flat scanner - Lexmark X2250 with CIS scan technology (Contact Image System), 48-bit, internal and external, 24-bit colour depth, 16-bit internal and 8-bit external greyscale of the optical resolution of $600 \times 1200$ dpi and a maximum scan area of $216 \times 297 \mathrm{~mm}$, and the above-described application ImageJ.

A modification of the method Kozlowski and Kozlowski [4] was also applied, consisting of using A4-size pads made of foil with inlayed 20 sectors, each corresponding to an initial dimension of lettuce leaf subject to $50 \times 50 \mathrm{~mm}$ scanning, which, depending on the selected scan resolution, was as follows: at $150 \mathrm{dpi} 294 \mathrm{x} 295 \mathrm{px}$, at $300 \mathrm{dpi}$ $590 \times 591 \mathrm{px}$. The differences arise from overwriting the macros when converting BMP to JPEG [23]. The reason of application of this solution was to gain the ability to multiply the number of operations with a single set of samples placed in the device, which also reduced the risk of deformation or displacement of portions of the sample in the device. After scanning of the designated sectors, they were saved separately in JPG files. Analysis of the images is done in ImageJ, the configuration of which consisted in graduating the parameters. Determination of the scale was performed after importing the image, based on the assignment of known distance in pixels to a known distance in metric unit [mm] (Fig. 1).

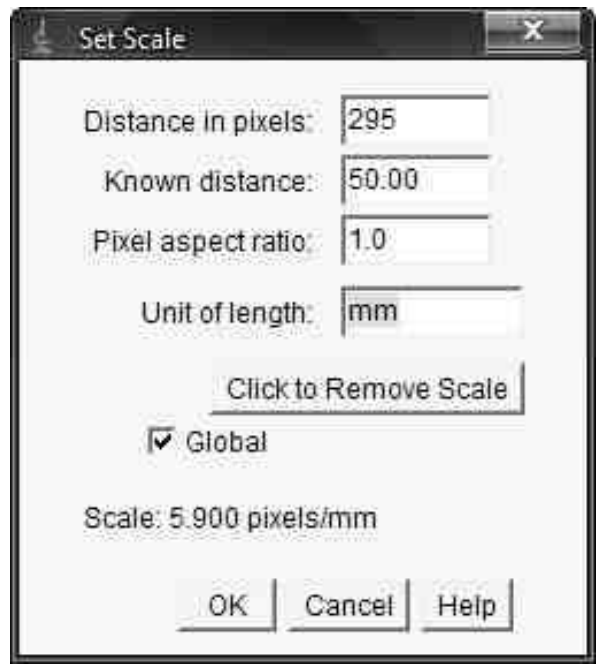

Fig. 1. Menu sailing image (Set scale)

In sub-menu Set measurements (Fig. 2) the types of measurements to be made and the manner of their presentation were defined. It was selected for the program to define the measured surface area (Area) and the number of pieces of food debris (Area fraction).

Before measuring operations, the image was dissected - Function - Colour threshold, defining the threshold value of the colour, brightness and colour intensity. 


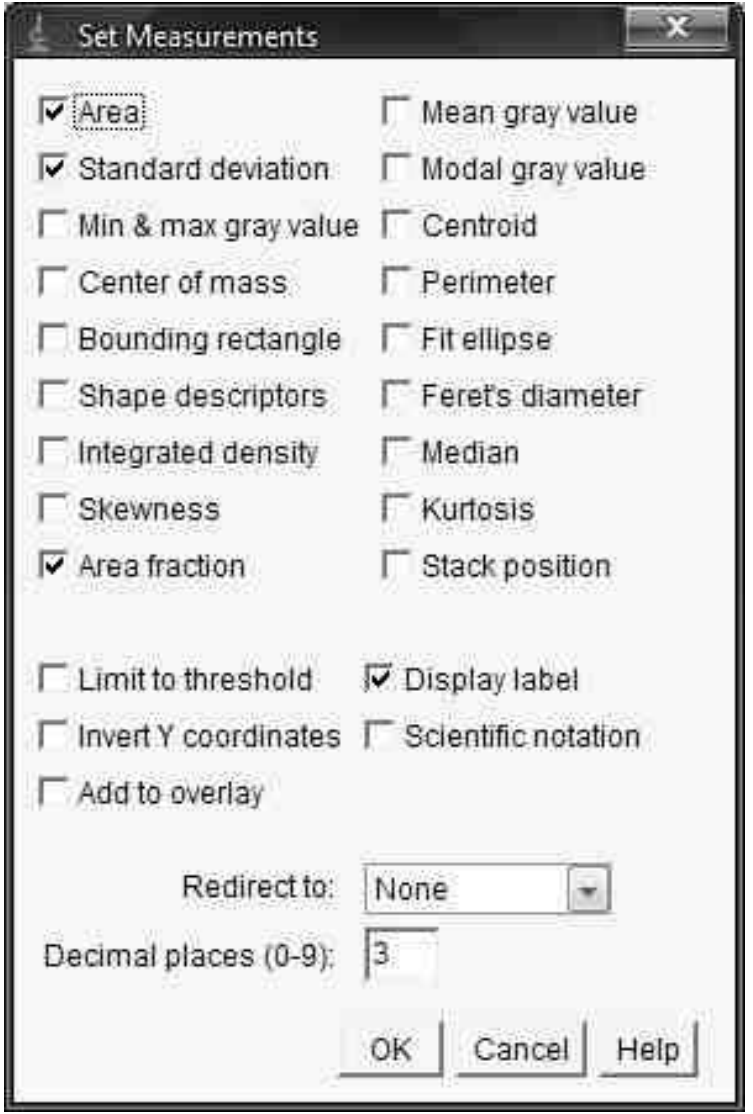

Fig. 2. Menu selection of measurements that have to make a program (Set measurements)
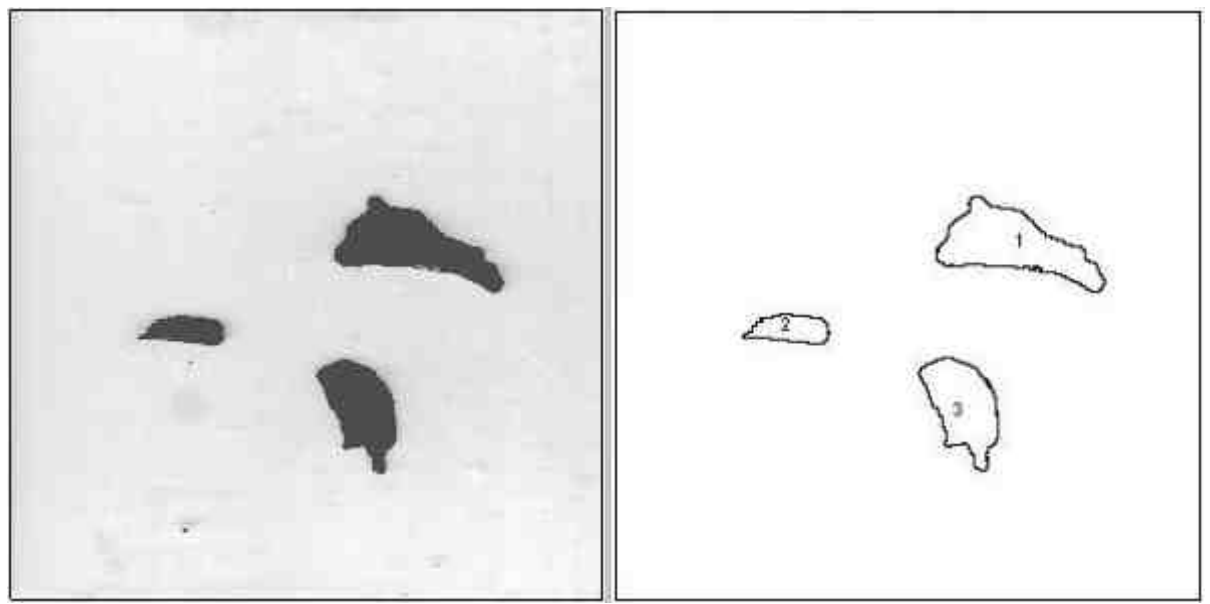

Fig. 3. The image before and after the conversion - the appointment of threshold values of colours 
The next step was the implementation of the analysis. In the Analyze particles window, the size of the minimum size object to be taken into account in the measurement was defined, as well as the method of presentation of the result. This tab also is rich in all kinds of options to refine the measurement, in this case the option Include holes (not considering in the results the holes in the analysed lettuce) is disabled.

The obtained data were recorded in the summary table exported to the format supported by Excel from Microsoft Office package. The surfaces of leaf fragments were expressed in $\mathrm{mm}^{2}$.

\section{Determination of the contents of the tested substance}

Simultaneously with the chemical analyses, the samples were collected in the form of leaf discs having a diameter of $1.1 \mathrm{~cm}$ cut from the same leaf of lettuce. The contents of each substance were determined by GC with detection of $\mu \mathrm{ECD}$ and their content in leaves given to snails was expressed in $[\mathrm{mg} / \mathrm{kg}]$ and in $\left[\mathrm{mg} / \mathrm{mm}^{2}\right]$.

\section{Analysis of results}

In lettuce, due to the large surface of transpiration, there may be considerable loss of water in a short time [24], therefore, before the actual experience with ImageJ, analyses of the change in the surface of the fresh leaves of lettuce after $24,48,72$ hours after the harvesting was performed. The obtained results of the analysis were used to determine the coefficient of wilting $\left(I_{w}\right)(1)$ to be used in later calculations:

$$
I_{w}=A_{L 0}-A_{L d}
$$

where: $A_{L 0}$ - surface of the fragment of lettuce with dimensions of $50 \times 50 \mathrm{~mm}$, right after harvesting; $A_{L d}$ - surface of the fragment of lettuce with dimensions of $50 \times 50 \mathrm{~mm}$ after a defined day of storage.

The obtained results were shown as the amount of consumed area $A\left[\mathrm{~mm}^{2}\right]$ of food per gram of body weight of animals in accordance with the formula (2):

$$
E=A_{i} / M_{i}
$$

in which $A$ indicates the surface of the consumed food (total area - area left after consumption), $M$ - snails' weight.

Using the results of the analysis of leaves for residuals $(R)$, and knowing the size of the consumed surface, one also made a simple calculation of the amount of collection of test substance by multiplying the amount of the consumption of lettuce and the level of residues expressed in $\left[\mathrm{mg} / \mathrm{mm}^{2}\right]$.

This value was used to determine the amount of collection of substance in the per gram of body of snail $\left(E_{R}\right)$ according to the formula (3):

$$
E_{R}=\left(A_{i} \cdot R_{i}\right) / M_{i}
$$

Additionally, the analyses results were used to calculate:

- $\quad$ modified index of deterrence (Kielczewski) $\left(I_{D}\right)$ expressed with the formula (4):

$$
I_{D}=\left[\left(C-E_{i}\right) /\left(C+E_{i}\right)\right] \cdot 100
$$

- $\quad$ and tastiness coefficient $I_{F}$ according to the formula (5):

$$
I_{F}=C / E_{i}
$$

in which $C$ denotes the area of food consumed in the control trial (g.b.m.), $E$ - the surface of food consumed in the tested combinations for the $1^{\text {st }}$ repetition (per g.b.m). 


\section{Conclusions}

Use of the ImageJ application described above and the method of assessing the impact of substances on the activity of feeding of pests, as well as the use of pads for the scanning the device, the replacement of discs with squares of known area, greatly accelerate the very process of image acquisition (scanning a large number of items at a time), and the presentation of results of the consumed per gram of body weight of the animal enables to perform the assessment of feeding activity, the analysis of the potential effectiveness $e g$ of pesticides for various insects characterized by sexual dimorphism, the grouping of environmental response for snails, for example from one family Arionidae, and listing the defects of plants treated with chemical crop protection products by pests species with similar consumption preferences, feeding on the same agricultural crops.

\section{References}

[1] Glasbey CA, Horgan GW. Image analysis in agricultural research. Quant Approach Syst Anal. 2001;23:4354. http://www.bioss.ac.uk/people/chris/wageningen.pdf.

[2] Zieliński KW. Komputerowa analiza obrazu biomedycznego, Wstęp do morfometrii i patologii ilościowej. (Computer biomedical image analysis, Introduction to quantitative morphometry and pathology). Warszawa: Wyd Nauk PWN; 2013.

[3] Kozłowski RJ, Górski R, Kozłowska M. Metody analizy obrazu w badaniu krzywej wzrostu grzyba Trichoderma harzianum występującego w uprawie pieczarki dwuzarodnikowej Agaricus Bisporus (Lange/Imbach). (Image processing methods in studies of growth model of the fungus Trichoderma harzianum found in button mushroom Agaricus Bisporus (Lange/Imbach) cultivation). Prog Plant Prot./Post Ochr Roślin. 2009;49(3):1285-1290.

[4] Kozłowski RJ, Kozłowski J. The computer system for the analysis of damages on oilseed rape leaves. J Res Appl Agric Eng. 2008;53(2):61-65. http://www.pimr.poznan.pl/biul/2008_2_KK.pdf.

[5] Stien LH, Suontama J, Kiessling A. Image analysis as a tool to quantify rigor contraction in pre-rigor-filleted fillets. Compt Electron Agr. 2006;50:109-120. DOI: 10.1016/j.compag.2005.08.012.

[6] Kalbassi MR, Lorestani R, Ghafle Maramazi J. Analysis of saline activator solution effects on sperm quality indices of Barbus sharpeyi by ImageJ software. Iran J Fish Sci. 2013;12(2):357-377. http://www.jifro.ir/files/site1/user_files_eb12be/eng/kalbasi-A-10-165-2-ea01964.pdf.

[7] Last AJ, Parkin CS, Beresford RH. Low-cost digital image analysis for the evaluation of aerially applied pesticide deposits. Compt Electron Agr. 1987;1(4):349-362. DOI: 10.1016/0168-1699(87)90005-6.

[8] Tukiendorf M, Szwedziak K, Sobkowicz J. Określenie czystości ziarna konsumpcyjnego za pomocą komputerowej analizy obrazu. (Determining the purity of consumer seed with the help of computer analysis of the image). Inż Roln. 2006;12(87):519-525. http://ir.ptir.org/artykuly/pl/87/IR\%2887\%29_406_pl.pdf.

[9] Mollaha BR, Hasanb A, Salamc A, Ali A. Digital image analysis to estimate the live weight of broiler. Compt Electron Agr. 2010;72:48-52. DOI: 10.1016/j.compag.2010.02.002.

[10] Rodríguez-Pulido FJ, Gómez-Robledo L, Melgosa M, Gordillo B, González-Miret ML, Heredia FJ. Ripeness estimation of grape berries and seeds by image analysis. Compt Electron Agr. 2012;82:128-133. DOI: 10.1016/j.compag.2012.01.004.

[11] Čermák P, Mazal P, Palovčíková D, Jankovský L. Application of image analysis in plant pathology and forest protection. J For Sci. 2006;52(7):316-323. http://www.agriculturejournals.cz/publicFiles/55117.pdf.

[12] ImageJ (Official Website) - http://imagej.nih.gov.

[13] Koh K-J, Park N-H, Kim K-A. Prediction of age-related osteoporosis using fractal analysis on panoramic radiographs. Imaging Sci Dent. 2012;42(4):231-235. DOI: 10.5624/isd.2012.42.4.231.

[14] Abramoff MD, Magalhaes PJ, Ram SJ. Image processing with Image J. Biophotonics Internat. 2004;11(7):36-42. http://www.imagescience.org/meijering/publications/download/bio2004.pdf.

[15] De Oliveira AG, Consolaro A, Junqueira JLC, Martins-Ortiz MF, Franzolin SOB. Analysis of predictors of root resorption in the orthodontic treatment (Part II). J Dent Oral Hyg. 2011;3(6):75-81. http://www.academicjournals.org/journal/JDOH/article-full-text-pdf/B884F6E5014.

[16] Choi YS, Park JK, Kang EH, Lee Y-K, Kim TK, Chung JH, et al. Cytokine signaling-1 suppressor is inducible by IL-1beta and inhibits the catabolic effects of IL-1beta in chondrocytes: its implication in the paradoxical joint-protective role of IL-1beta. Arthritis Res Ther. 2013;15:R191. DOI: 10.1186/ar4381. 
[17] Demmerle J, Koch AJ, Holaska JM. The nuclear envelope protein emerin binds directly to histone deacetylase 3 (HDAC3) and activates HDAC3 activity. J Biol Chem. 2012;287:22080-22088. DOI: 10.1074/jbc.M111.325308.

[18] Xu Y-Z, de la Rosa Santamaria R, Virdi KS, Arrieta-Montiel MP, Razvi F, Li S, et al. The chloroplast triggers developmental reprogramming when MUTS HOMOLOG1 is suppressed in plants. Plant Physiol. 2012;159:710-720. DOI: 10.1104/pp.112.196055.

[19] Zhang J-Q, Shen M, Zhu Ch-Ch, Yu F-X, Liu Z-Q, Ally N, et al. 3-Nitropropionic acid induces ovarian oxidative stress and impairs follicle in mouse. PLoS One. 2014;9(2):e86589. DOI: 10.1371/journal.pone.0086589.

[20] Raub ChB, Unruh J, Suresh V, Krasieva T, Lindmo T, Gratton E, et al. Image correlation spectroscopy of multiphoton images correlates with collagen mechanical properties. Biophys J. 2008;94:2361-2373. DOI: 10.1529/biophysj.107.120006.

[21] Sanger TJ, Sherratt E, McGlothlin JW, Brodie ED, Losos JB, Abzhanov A. Convergent evolution of sexual dimorphism in skull shape using distinct developmental strategies. Evolution. 2013;67(8):2180-2193. DOI: 10.1111/evo.12100.

[22] Hindman BW, Gizon L, Duvall TL, Haber DA, Toomre J. Comparison of solar subsurface flowers assessed by ring and time-distance analyses. Astrophys J. 2004;613:1253-1262. http://www2.mps.mpg.de/homes/gizon/PAPERS/apj_613_1253.pdf.

[23] Anjali A, Aggarwal H. BMP to JPEG - the conversion process. J Global Res Comp Sci. 2011;6(2):145-150. http://www.jgrcs.info/index.php/jgrcs/article/view/74/74.

[24] Idaszewska N, Bieńczak K. Koncepcja transport sałaty na duże odległości w stanie świeżym. (The conception of fresh lettuce transport for long distance). J Res Appl Agric Eng. 2013;58(2):52-54. http://www.pimr.poznan.pl/biul/2013_2_11IB.pdf.

\title{
ZASTOSOWANIE PROGRAMU ImageJ DO OCENY USZKODZEŃ ROŚLIN PRZEZ ŚLIMAKI
}

\author{
${ }^{1}$ Zakład Ekotoksykologii, Pozawydziałowy Zamiejscowy Instytut Biotechnologii Stosowanej i Nauk \\ Podstawowych, Uniwersytet Rzeszowski, Kolbuszowa \\ ${ }^{2}$ Zakład Botaniki, Pozawydziałowy Zamiejscowy Instytut Biotechnologii Stosowanej i Nauk Podstawowych \\ Uniwersytet Rzeszowski, Kolbuszowa
}

\begin{abstract}
Abstrakt: Testy laboratoryjne $\mathrm{z}$ zastosowaniem analizy obrazu stanowią jeden z rodzajów metod eksperymentalnych w ochronie roślin. Są one wykorzystywane podczas oceny uszkodzeń roślin przez szkodniki, użyteczne także w testowaniu skuteczności działania substancji aktywnych środków ochrony roślin. Najpopularniejsze wśród takich analiz są tzw. „testy krążkowe”, polegające na podawaniu owadom, ślimakom fragmentów liści i mierzeniu wielkości konsumowanej powierzchni. W artykule zaprezentowano metodę służącą do analizy uszkodzeń liści sałaty przy zastosowaniu aplikacji ImageJ. Zaproponowano również sposób przedstawiania uzyskanych wyników. Procedura ta może znaleźć zastosowanie w różnych analizach biologiczno-przyrodniczych oraz podczas oceny preferencji pokarmowych szkodników. Dostęp do aplikacji ImageJ jest darmowy, a elastyczna konfiguracja, pozwalająca na dowolne ustawienie parametrów programu, możliwość pracy w różnych środowiskach systemowych i niewielkie wymagania sprzętowe umożliwiają wykonanie wielu dokładnych pomiarów w krótkim czasie bez konieczności zakupu drogiego specjalistycznego sprzętu.
\end{abstract}

Słowa kluczowe: ImageJ, ślimak, uszkodzenia roślin, analiza graficzna, analiza obrazu, ocena uszkodzeń 